A 208

\title{
JAXA750kW アーク加熱風洞における光学的気流計測技術の整備

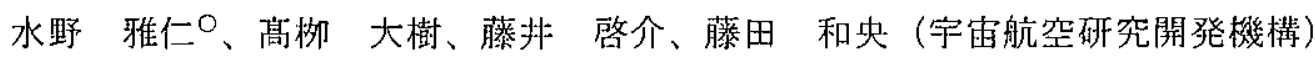 Preparation of optical flow diagnostics technique at JAXA 750kW arc-heated wind tunnel
}

\author{
Masahito MIZUNO, Hiroki TAKAYANAGI, Keisuke FUJII and Kazuhisa FUJITA
}

\begin{abstract}
In order to provide the flow conditions of high-enthalpy flow such as arc-heated wind tunnel and inductively coupled plasma (ICP)-heated wind tunnel accurately, the optical flow diagnostics techniques has been prepared. Two types of non-intrusive optical diagnostics method such as LIF (Laser-Induced Fluorescence) and emission spectroscopy is conducted. Two-photon LIF diagnostics system for atomic oxygen has been conducted in the $750 \mathrm{~kW}$ arc heated wind tunnel in JAXA in order to obtain velocity, translational temperature and number density of atomic oxygen simultaneously. Absolute atomic number density was obtained with a calibration technique by a xenon reference gas cell. Radiation spectroscopy for ICP-heated wind tunnel is conducted to improve accuracy of the radiation code and to evaluate the flow properties in the test section of the wind tunnel in detail. Molecular temperatures are determined by the spectrum fitting method in the aid of the radiation code, SPRADIAN2.
\end{abstract}

Keywords: High enthalpy flow, Optical flow diagnostics, Laser induced Fluorescence, Spectroscopy

\section{1. 本研究の目的}

再突入機や惑星探查機周りの気流の物理化学的性質は、 熱防護系の設計に非常に重要である。スペースシャトル 開発時には、機体周りの熱化学的非平衡現象に関する理 解が不充分であり、過大な設計を行なうことを余媛なく されていた。近年においても、気層の非平衡反忘岳デル に含まれる不確実性が依然大きく、地上実験設薉による 実験が重要である。そのような大気突人環境を模擬する 一般的な地上実験設備として、アーク加熱風洞や誘導加 䓡プラズマ風洞がある。これらの風洞における温度、気 流組成、速度などの気流物理量を正確に测定することが、 非平衡反応モデルの信頼性を向上させるためには重要な 技術課題である。それらの状態量を精度よく得る方法と して、発光分光法、レーザー吸収分光法、レーザー誘起 営光法(LIF 法)等の光学式計測法がある。

それぞれの計測法から得られた気流物理量を相互に比 較険討することで、より信頼性の向上した気流データを 得ることが出来ると考えている。この気流計測技術が整 備出来れば、一梯流中の組成に加えて、推整層前後にお ける化学組成・温度変化を実測し、空力加熱予測高精度 化に必須である化学反応モデル・表面触媒性モデルの改 良・検証を進めることが出来るようになる。従って、 JAXA 研究開発本部では、高エンタルビ気流物理量を高 精度で評価できる光学的気流計測技術の整備を進めてい る。これまでに、発光分光法 "、レーザー吸収分光法の 適用を試加てきた。さらに LIF 装置の等入を始め、氮流
物理量の評価等のための有望な測定法として注目してい る。

本踰文では、これまでJAXA 研究開発本部で実施した LIF 法扰よび発光分光法による高エンタルピ気流計测結 果について、その計測例を紹介与る。

\section{2. 高エンタルピ気流計測法}

JAXA 研究開発本部には、高エンタルピ風洞として、 $750 \mathrm{~kW}$ アーク加熱風洞 ${ }^{21}$ および $110 \mathrm{~kW}$ 誘尊加熱プラズマ 風洞”が整備されている。

アーク加熱風洞は、材料の高加熱が奏現出来るので、 各程耐熱試験に最適である。流れは極超音速流で、熱的 化学的非平衡流である。アーク加熱器内圧力も比較的高 压（およそ一気圧程度まで）に設定出来る。但し銅製電 搬の溶融による気流中へのコンタミネーションが発生け るという欠点がある。さらに、気流の非平衡性から、推 定された気流組成は、反忘モデルなとに㥛めて強く依存 してしまう。一方、誘導加熱ブラズマ風洞は、アーク加 染風洞に比べると比較的低加熱率、低玨力条件下での運 用となる。そして現在は、覀音速気流とすることで、熱 的化学的平衡流を仮定し、気流物理量の解析を容易にし ている。また、無電極放電であるために、気流中へのコ ンタミネーションがなく、表面反応を伴う実䮖には高品 货の気流を奏現することが出来る。

高精度空力加熱子測のためには、初めにそれぞれの風 洞の気流状態を正確に把据出来ることが雷要である。そ こで我々が着目している备光学式計测法についてその概 
略を述バる。

受的的計測法である発光分光法は、ブラズマから自然 に放射される発光スペクトルを計测、分析することによ って温度や組成などを推定する計測法である。熱的化学 的平衡流である誘導加熱ブラズマ気流では、気流組成に おける不確定性は最小腿に抑えることが出来るので、同 計測法は反応モデルの検証に極めて有用な計測法である。 これまでに、同風洞において、スペクトルマッチング法 により、気流温度と組成を推定することが出来た ${ }^{4 !} 。$ の計測例を後述する。これに対して、アーク加熱気流に 発光分光を適用し、スペクトルマッチング法により気流 状態を評洒しようとしても、熱的化学的非平衡流である ため適用が困踓であった。

能動的計測法である吸収分光法は、分子の振動、回転 に関寸るエネルギー淮位間の赤外吸収遷移を利用してい る。比較的安価にシステムを構築することが可能であり、 また可般性に優れている。我々は、窒素原子等を測定対 象として半導体レーザーによる吸収分光計測を行ったが、 淮安定準位の数密度が低いために、JAXA 研究開発本部の アーク加熱風洞ではまだ適用出来ていない。

両計測法はともに、視線方向の積分值を計測しており、 架間上の任意の点に拧けるデー夕あるいはその分布を得 ることが出来ないという欠点がある。

同じく能動的計測法であるレーザー誘起営光法は、レ 一ザーにより電子励起状態に励起させ、その後基底状態 に遷移する際の営光を観測する手法である。そして対象 とする分子・原子の基底状態の物理量を直接得ることが 出来ること、空間分布としてデータが得られることとい う大きな特長少ある。但し、数密度の定量計測には較正 計测が必要であることやシステムが大規模で高偳である 等の欠点がある。

保有する高エンタルピ風洞では、特にアーク加熱風洞 気流について、その複雑な流九場であるということから、 並進／回枟／振動／電子励起に関する各温度、原子・分 子の数密度、流速などが未知である。誘遒加熱プラズマ 風洞に执いても同様の物理量を得ることが必要であり、 これらの量は全て上述の三種類の計測法を統合すること によって求めることが可能である。

我々が垷在最も注目している気流物理量の一つが、気 流中の各化学種の解離度である。解碓度は表面触媒性に 関係し、再突入空力加熱予測高精度化に影響を与える。 誘導加熱プラズマ風洞では、熱的化学的平衡が仮定出来 るので、解嵟度を推定することは可能である。しかしな かららアーク加熱風洞では、現段階では正確に把握出来て いない。スペースシャトル等の突入機周りの気流エンタ ルピはおよそ 20〜30MJ/kg に達しており、そのエンタル ピ条件下では酸素 $(0)$ はほぼ全解離しているが、窒䋕 $(\mathrm{N})$ は全解触しておららず、その解嵟度は不明である。

このエンタルピ值はアーク加熱風洞でほぼ模擬出来る ので、アーク加䓡蚛洞で、表面触媒性効果を含む空力加
爇の影響について実験を行なう場合、窒素解離度あるい は䇪奖原子数密度を推定できることが重要である。その ためには、基底状態を直接励起して情報を得ることが高 精度化に必要であり、従って LIF 法が最適である。即ち LIF 法では、N-LIF 法適用が最終目標である。但しN原子 の淤起波長は $205 \mathrm{~nm}$ と非常に短波長なのでその光强度が 微弱であり、かつ解離度が低いため総监光信号强度が微 弱であるので、技街的に困難を伴う。そこで前段階とし て、充分解䧹度が高くかつ励起波長が $225 \mathrm{~nm}$ で一定の光 強度があり比較的計測がしやすい 0-LIF 法の適用をまず 試みた (5)

\section{3. レーザー誘起蛍光法（LIF 法）}

\section{1 測定装置}

本実験では $225.6 \mathrm{~nm}$ 近偿に励起波長を有する酸素原子

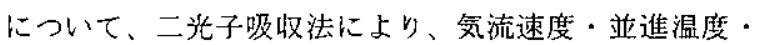
数密度を推定した。それぞれの物理量は、励起波長のド ップラーシフト・ドップラー桩がりの半值全幅・キセ， ンガスによる較正結果上の比較によりそれぞれ求めた。

实駼系をFig. 1 に示す。Nd:YAG レーザー、色素レーザ 一、波長変換器 (非線形光学結晶) から棈成される。 225. $6 \mathrm{~nm}$ 近傍でレーザー波長を掃引し、各励起波長にお ける举光をICCD カメラで取得する。レーザー穆引波長は 波長計により測定した。レーザー光は、気流中心軸に刘 して 50 度の角度で気流前方から斜入射させている。酸潔 原子からの蛍光は極めて微弱であるため、測定では 50 枚の蛍光画像を積算して S/N 比向上に努めた。また、計 澌中に Nd:YAG レーザー光強度が変動することによる学 光信昘强度のばらつきは、エネルギーモニターに上り备 レーザーショットの强度を計測して、これを規格化する ことにより補正した。風洞の運抎条件をTable 1に示す。

\section{2 実験結果}

酸媇原子の蛍光画像例をFig. 2 亿示寸。画像の左端少 直径 $40 \mathrm{~mm}$ の円柱形状 $\mathrm{SiC}$ 供試体である。測定采の設犆位 琶の関係上、気流が右加ら左に流れる向きに撮影してい る。既実施の空間分解発光分光計測（分解能は $3 \mathrm{~mm}$ ) に よる衝慗波離脱距離は10 m 以下であり、本計測で推定さ れる䧿脱距虧 $(7 \mathrm{~mm}$ 程度) とほぼ同等である。

供試体表面からの距離に対寸る蛍光強度の分布からド ッブラーシフト量を求め、衝整層内外の流速差 $\delta$ vを推定 オると、 $\delta v=3.6 \pm 0.4 \mathrm{~km} / \mathrm{s}$ となった。一方酒井ら”は、 ARCFL03 計算コードを用いて、実験と同じ本風洞気流条 作に対して自由流中の流速を、 $\delta v=4.6 \mathrm{~km} / \mathrm{s}$ と求めてい

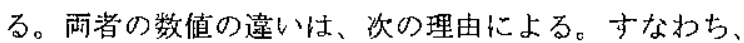
衡然屏内での流速は㴈対的に0ではなくある有限の值で むる。また流速べクトルは供試体表面に対して重直では 
ない。そのために CFD 結果から得られた流速よりも、実 験から求めた流速差の方が小さい値となると考えられる。

样々な風洞運転条件で推定した酸素原子数密度分布を

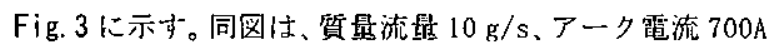
の風洞運転条件での結果である。実線は、酒井ら》の計 箅結果である。実験結果の方が䯩い值になっているが、 その原因として、Xe 参照ガスセルでの実験精度が影響し ている可能件があるため、その対策を施し、計測精度を 上げていくのが今後の椋題である。

\section{4. 発光分光法}

$110 \mathrm{~kW}$ 就導加熱プラズマ風洞流れに詨して、輻射計算 codeの精度を向上させ気流条件を評洒するために、発光 分光計测に関寸る研究を行なっているい。アーク加熱気 流は熱的化学的非平衡流であり複雄である。そこではじ めに、垔音速流で熱的化学的平衡流であるため比較的単 純な誘遒加熱プラズマ瓜洞流れに対して分光計测を行っ

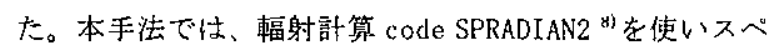
クトルフィッティングによって、分子温度と成分涪度を 求めた。実験では、分子温度の半径方向分布を逆ア一心 ル変換によって求奴。

風洞迺忶条件は、電力 $90 \mathrm{~kW}$ 、質量流量 $1.8 \mathrm{~g} / \mathrm{s}$ であり、 これにより $15 \mathrm{MJ} / \mathrm{kg}$ から $18 \mathrm{MJ} / \mathrm{kg}$ の総エンタルピが得ら れている。作動気体証気と窒素である。

気流半径方向の温度分布をFig. 4 に示す。この温度の 半径方向分布を用いて、流れのエンタルビを理諭的に計 算することが壮来る。気流中心から $25 \mathrm{~mm}$ 以内の流れの総 エンタルピの平均值は、垒装流に対して $13.4 \pm 1.0 \mathrm{MJ} / \mathrm{kg}$ であり、空気流に対して $13.7 \pm 1.1 \mathrm{MJ} / \mathrm{kg}$ であった。こ れに対して、热バランス法による計測值は、雨気体とも 17. $7 \pm 1 \mathrm{MJ} / \mathrm{kg}$ であり、計算值よりも30\%高い。熱バラ ンス法により求めたエンタルピは、熱輻射と橉造材料人

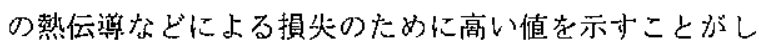
ばしば指掂されている。この理由のため、分光学的に求 めた流れのエンタルピ值は、局所熱平衡下でより正確な 値であると考えられる。

\section{5. まとめ}

再突入機り熟空力設計技術向上に久かせない反応モデ 儿等の実験的検証に極めて虏意義であるアーク加熱風洞 及び誘導加熱プラズマ風洞に、各種の光学的気流計測技 術を適用占ることが有用であることを述べた。そして、 JAXA 研究閒発本部で整啃を進めている光学的父流計測 法である発光分光法、レーザー吸収分光法、レーザー誘 起虽光法を紹介し、現在の整俑目摽を述べた。そして、 それぞれの計測手法を概覞し、凧洞物理量の推定には、 各種計測法を組み合わせて、統合的に評洒す心゙きである ことを述べた。

\section{参 考 文 献}

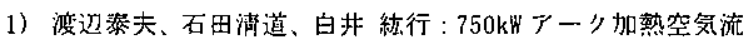
におけるNO 分子バンド発光の分析、NAL TR-1417，2000.

2) R. K. Smith, D. A. Wagner, J. Cunninghan, J. H. Painter, H. Itagaki, Y. Watanabe and S. Hasegawa, "High enthalpy material test facility design improvements in Japan," AIAA paper 94-2592, 1994.

3) Takeshi Ito, Kiyomichi Ishida, Masahi to Mizuno, Takahiro Suni, Takeshi Matsuzaki, Junsei Nagai and Hiroshi Murata, "110klt new high enthalpy wind tunnel heated by inductively-coupled-plasma," AIAA paper 2003-7023, 2003.

4) Kazulisa Fujita, Masahi to Mizuno, Kiyomichi Ishida and Takeshi Ito, "Spectroscopic flow evaluation in inductively coupled plasma wind tunnel," Journal of Thernophysics and Heat Transfer, Vo1.22, No.4, 2008, pp. 685-694.

5) Masahito Mizuno. Takeshi Ito, Kiyomichi Ishida and Junsei Nagai, "Laser induced fluorescence of nitric oxide and atomic oxygen in an axc heated wind tunnel," AIAA paper 2007-4405, 2007.

6) Hiroki Takayanagi, Masahito Mizuno, Keisuke Fujii, Toshiyuki Suzuki and Kazuhisa Fujita, "Arc heated wind tunnel flow diagnostics using laser-induced fluorescence of atomic species," AIAA paper 2009-1449. 2009.

7) Sakai Tadaharu, Suzuki, Toshiyuki, Fujita, Kazuhisa, and I to Takeshi, "Calculation of High-Enthalpy Aerothermal Environment in an Arc jet Facility, "Journal of Thermophysics and Heat Transfer, Vol, 21, No. 1, pp. 249-252, 2007

8) Fujita Kazihisa and Takashi Abe, "SPRADIAN, Structured Package for Radiation Analysis:Theory and Application," The Institute of Space and Astronautical Science Report 669, 1997.

Table 1 Experimental conditions

\begin{tabular}{|l|l|}
\hline Operational condition & $20 \mathrm{MJ} / \mathrm{kg}(700 \mathrm{~A}, \quad 10 \mathrm{~g} / \mathrm{s})$ \\
\hline Working gas & Simulated air \\
\hline $\begin{array}{l}\text { Nominal Mach number at } \\
\text { nozzle exit plane }\end{array}$ & 4.8 \\
\hline $\begin{array}{l}\text { Cold wall heat flux at } \\
\text { flow centerline } \\
\text { (cylindrical shape) }\end{array}$ & $2.48 \mathrm{MW} / \mathrm{m} 2$ \\
\hline
\end{tabular}




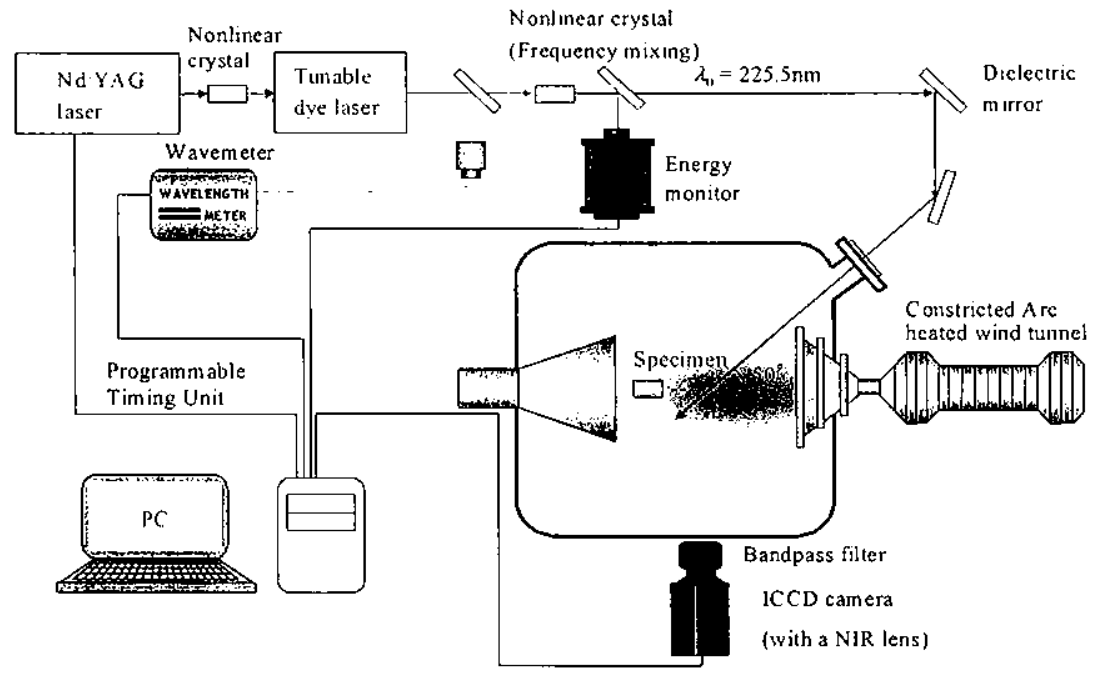

Fig. 1 Experimental setup of O-LIF system for arc-heated wind tunnel

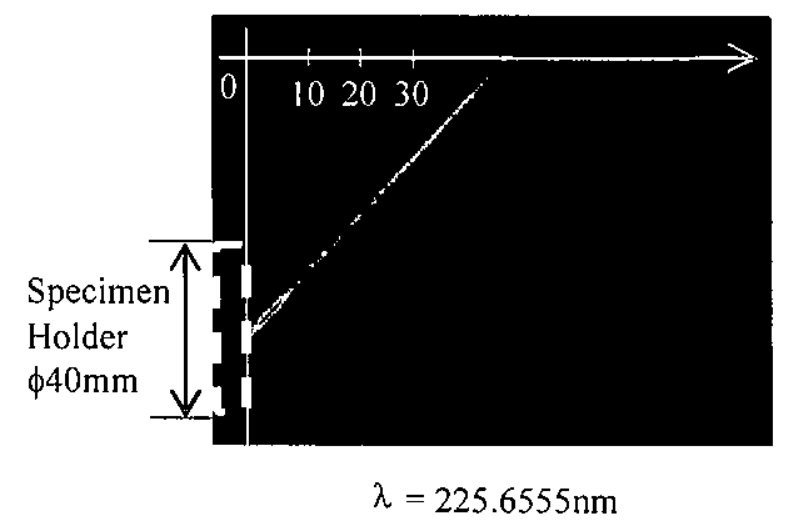

Fig. 2 Example photos of the LIF signals from atomic oxygen at several wavelengths $(\dot{m}=10 \mathrm{~g} / \mathrm{s}, I=700 \mathrm{~A})$

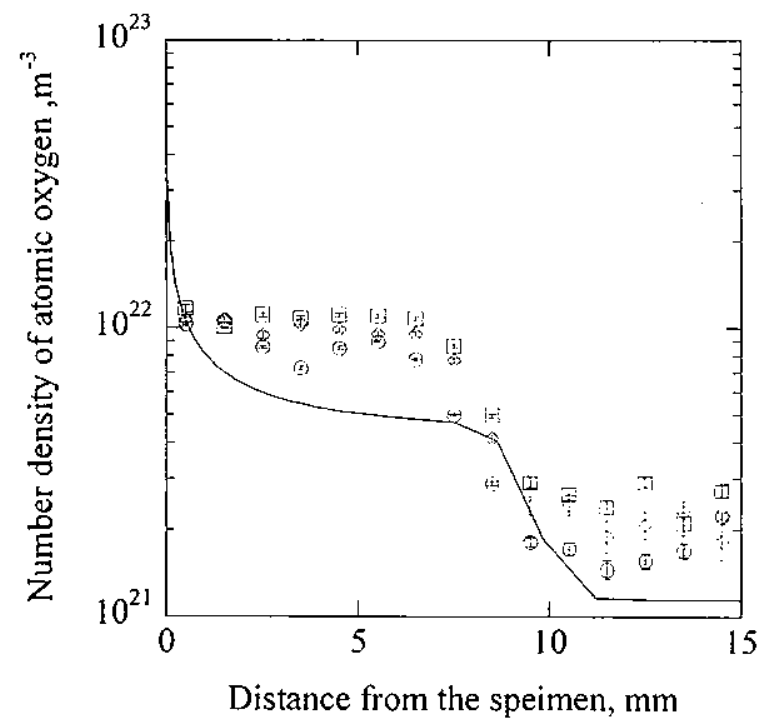

Fig. 3 Number density of atomic oxygen in the arc heated wind tunnel $(\dot{m}=10 \mathrm{~g} / \mathrm{s}, I=700 \mathrm{~A})$ :

Each point shows the experimental results and solid line shows the calculated one.

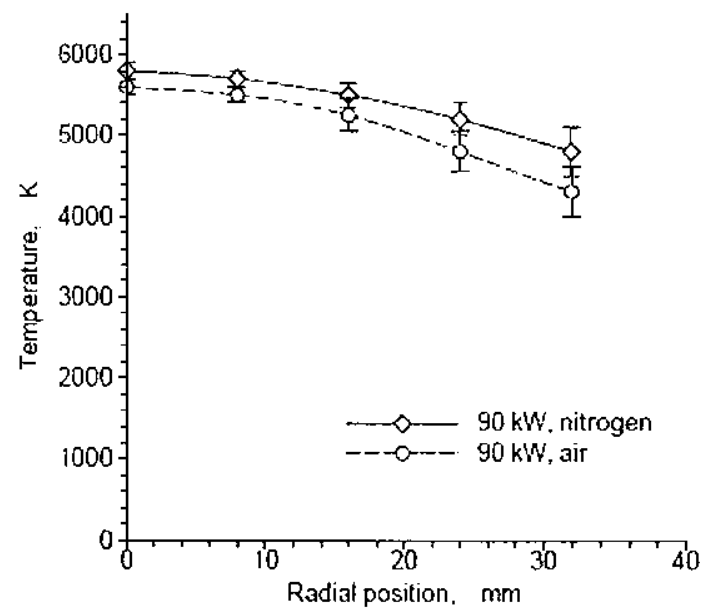

Fig. 4 Temperature distribution of radial direction input electrical power $=90 \mathrm{~kW}$, ambient pressure $=10 \mathrm{kPa}$, mass flow rate $=1.7 \mathrm{~g} / \mathrm{s}$ for nitrogen flow, $1.8 \mathrm{~g} / \mathrm{s}$ for air flow, respectively. 